\title{
Palenie tytoniu podczas I wojny światowej
}

\author{
Richard F. Mould
}

Niniejszy artykuł podejmuje temat, który pojawił się już na łamach Nowotworów [1] i przedstawia wybrane anegdoty i ilustracje związane z historią palenia tytoniu. Praca skupia się na omówieniu kwestii palenia fajki i papierosów podczas I wojny światowej i przywołuje zwyczaje żołnierzy z armii różnych państw. Inspiracją do napisania tego artykułu była niedawna wystawa w Mercer Art Gallery w Harrogate w Wielkiej Brytanii, zatytułowana Brangwyn's War: Posters of the First World War (Wojna Brangwyna: Plakaty z I Wojny Światowej) [2, 3]. Frank Brangwyn (1867-1956) urodził się w Bruges w Belgii jako Guillaume François Brangwyn. Nie był znany szerszej publiczności, jednak w gronie znawców sztuki i fotografii cieszył się uznaniem. Podczas I wojny światowej motyw palenia tytoniu pojawiał się nie tylko w formach ulotnych, takich jak plakaty czy kartki pocztowe, na litografiach i obrazach — lecz także między innymi w popularnych piosenkach marszowych, czy też jako część słynnego prezentu [Princess Mary's tin box] ofiarowywanego wszystkim brytyjskim żołnierzom i marynarzom z okazji Bożego Narodzenia w 1914 roku przez księżniczkę Marię, jedyną córkę króla Jerzego V i królowej Marii. Tytoń odegrał też ważną rolę w historii duchownego i kapelana Geoffreya Studderta Kennedy'ego, znanego jako Woodbine Willie. Dobrym pretekstem dla niniejszego artykułu była również setna rocznica wybuchu I wojny światowej.

\section{Tobacco smoking in World War I}

This article follows an earlier Nowotwory publication [1] on anecdotal data relating to tobacco smoking. It concentrates pipe \& cigarette smoking in World War I and relates to the soldiers of many countries. My impetus for the review, was a recent exhibition in Harrogate's Mercer Art Gallery in the United Kingdom, which was entitled Brangwyn's War: Posters of the First World War, [2, 3]. Frank Brangwyn who is largely unknown, except to art \& photography specialists, was born in Bruges, Belgium in 1867, as Guillaume François Brangwyn, and died in 1956. Tobacco is mentioned in WWI ephemera not only in posters, postcards, lithographs and paintings, but also finds an appearance in a popular marching song, in the gift [Princess Mary's tin box] given to all British soldiers \& sailors for Christmas 1914 by Princess Mary, the only daughter of King George V and Queen Mary, and in the story of the clergyman Woodbine Willie. This brief review is also appropriate because of the centenary of the outbreak of WWI in 1914.

NOWOTWORY Journal of Oncology 2015; 65, 4: 341-346

\section{Litografia Franka Brangwyna: brytyjscy żołnierze pod Ypres}

Litografia Franka Brangwyna (ryc. 1) przedstawiająca brytyjskie oddziały pod Ypres [2-4] powstała na zamówienie Soldiers \& Sailors Tobacco Fund w formie plakatu, pocztówki i znaczka. Niektóre egzemplarze opatrzone były podpisem „Uczyńmy co w naszej mocy, aby nigdy nie zabrakło im fajki ani papierosów". Na innych natomiast można było przeczytać:„,To znamienne, że niemal każdy list z frontu zawiera proś- bę o «coś do palenia»".Wieża znajdująca się w tle tej litografii to dzwonnica Sukiennic w Ypres - imponującego gmachu mieszczącego również ratusz, w swoim czasie jednego z największych handlowych budynków średniowiecznej Europy. 22 listopada 1914 roku niemieckie bomby zapalające uderzyły w budynek sukiennic. Drewniane rusztowania wokół gmachu, rozstawione przez miejscowego kamieniarza, który w chwili ataku kończył odbudowę dzwonnicy — stanęły w ogniu, a pożar zaczął się rozprzestrzeniać. Jak stwierdził 


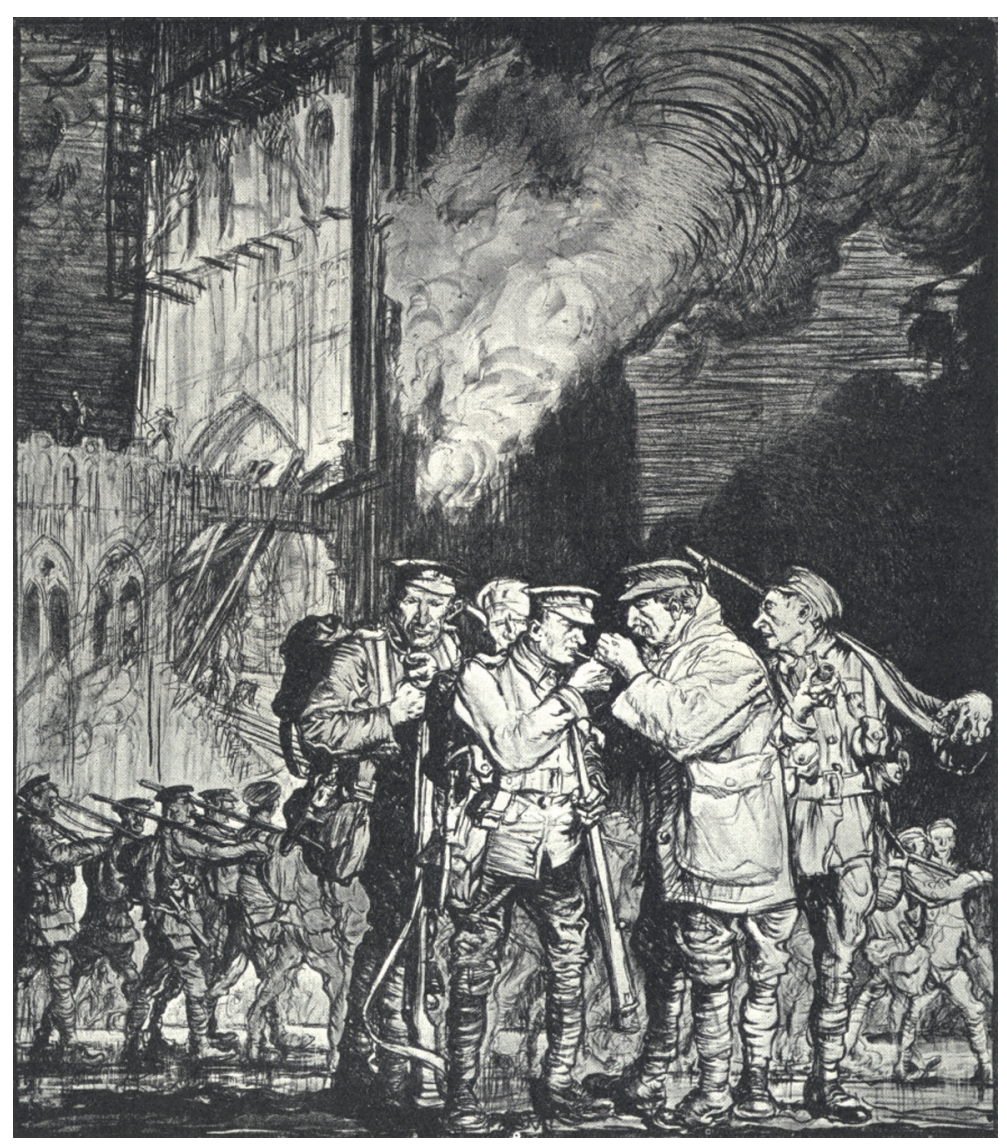

Rycina 1. Brytyjskie oddziały pod Ypres [3]

Horner [2], „podczas pierwszej bitwy pod Ypres, w październiku i listopadzie 1914, cesarz niemiecki nakazał swoim żołnierzom >Zdobyć Ypres lub zginąć<. Większość z nich zginęła. Ponad 17500 Niemców w dwunastu dywizjach zaatakowało na froncie o długości dziewięciu mil mniej niż 8000 Brytyjczyków, lecz nie zdołali ich przezwyciężyć".

\section{Brytyjscy, niemieccy i amerykańscy żołnierze}

Zanim wprowadzono termin „palenie”, nawyk ten określano mianem „suchego pijaństwa”. Podczas wojny, wraz z regularną racją rumu, uznawane było za skuteczny środek łagodzący stres i zwalczający nudę. Słynne pudełko z prezentem od księżniczki Marii na Boże Narodzenie 1914 roku zawierało tytoń dla żołnierzy brytyjskich oraz żołnierzy z kolonii [2]. W armii niemieckiej dostawy tytoniu były solidne i obfite. Jünger [5] odnotował: „obraz żołnierza, który towarzyszy mi od tamtych dni, to wartownik w spiczastym, szarym hełmie, z pięściami w kieszeniach wielkiego płaszcza, stojący za otworem strzelniczym i wydmuchujący dym z fajki tuż nad kolbą karabinu". Również w słynnej książce Ericha Marii Remarque'a Na Zachodzie bez zmian [6] podkreślono znaczenie zaopatrzenia w tytoń:„Najważniejsze jest jednak, że dostaliśmy także podwójne racje tytoniu. Dla każdego po dziesięć cygar, dwadzieścia papierosów i dwie kromki tytoniu do żucia, to wcale przyzwoicie"1 ${ }^{1}$.

Gdy Amerykanie przystąpili do wojny w 1917 roku, żołnierze od razu otrzymali swoją," porcję tytoniu”. Palenie papierosów i fajki tak silnie powiązano z męskością i patriotyzmem, że tych, którzy w USA sprzeciwiali się dostarczaniu piechurom papierosów, uznawano za zdrajców. Gdy I wojna światowa dobiegła końca, żołnierze we wszystkich krajach palili nadal, a przemysł tytoniowy przynosił coraz większe zyski [2].

\section{Pudełko księżniczki Marii, Boże Narodzenie 1914}

Podczas I wojny światowej powołano tysiące funduszy zbierających środki na niezliczone cele. Zapewne jednym z najbardziej znanych był Christmas Gift Fund, zainicjowany 14 października 1914 przez księżniczkę Marię, jedyną córkę króla Jerzego V i królowej Marii. Inicjatywa ta zaowocowała stworzeniem jednej z najtrwalszych i najbardziej rozpoznawalnych pamiątek z czasów I wojny światowej, Princess Mary's Gift Box — pudełka księżniczki Marii (ryc. 2). Przyświecała jej idea, aby każdy żołnierz służący królowi za granicą w dzień Bożego Narodzenia 1914 roku otrzymał „dar od narodu".

${ }^{1}$ Erich Maria Remarque, Na Zachodzie bez zmian, tłum. Stefan Napierski, Warszawa, 1996. 


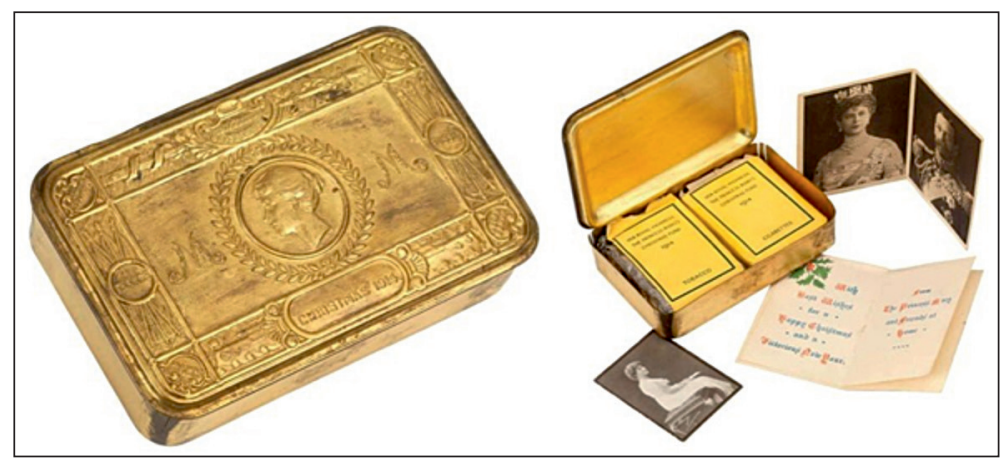

Rycina 2. Pośrodku pokrywki pudełka znajduje się podobizna głowy księżniczki Marii otoczona wieńcem laurowym. Na dolnej krawędzi widać okręt bojowy sunący przez wzburzone morze. Na wieku umieszczono też sojuszników: Belgię, Japonię, Czarnogórę, Serbię, Francję i Rosję. [Dzięki uprzejmości: Imperial War Museum w Londynie]

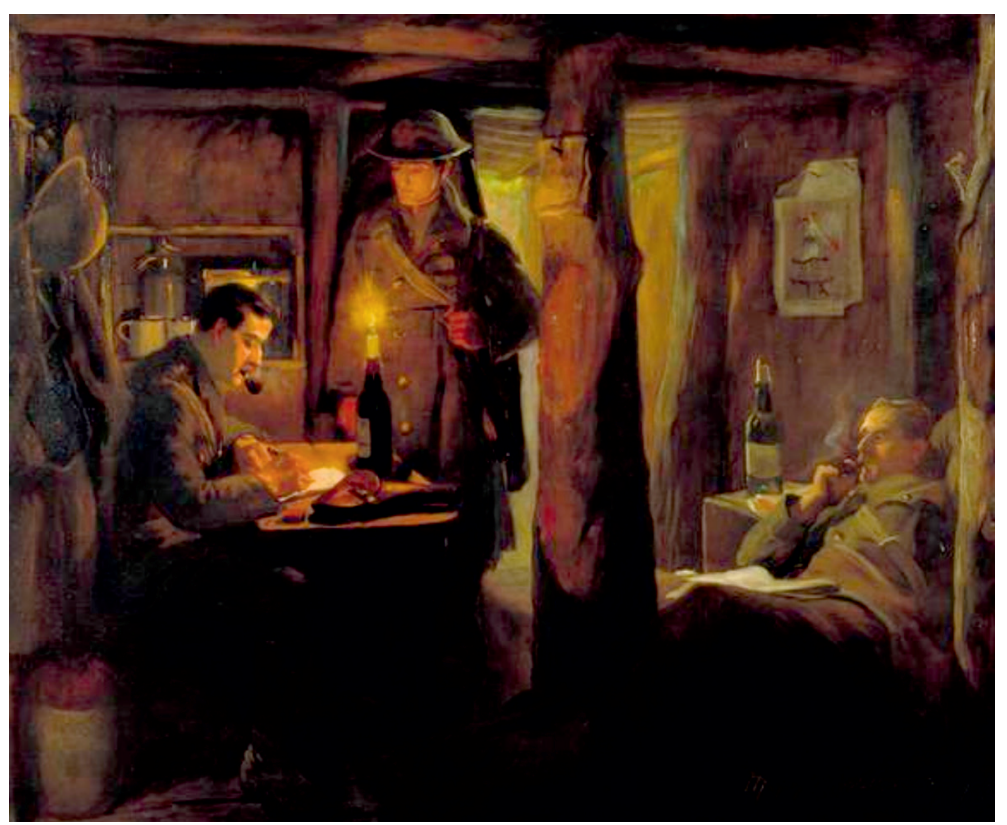

Rycina 3. Ziemianka komendanta. [Dzięki uprzejmości: Imperial War Museum, London]

Zawartość tłoczonego mosiężnego pudełka nie dla wszystkich była jednakowa. Oficerowie i żołnierze w służbie czynnej przebywający na morzu lub na froncie otrzymywali pudełko zawierające fajkę, zapalniczkę, uncję tytoniu i 20 papierosów w charakterystycznych żółtych i opatrzonych monogramem bibułkach. Niepalący i chłopcy otrzymali w zamian srebrne niezawodne ołówki, umieszczone w mosiężnej łusce naboju kaliber 0,303 (wprowadzony w 1888 roku był przepisowym kalibrem armii brytyjskiej podczas obu wojen światowych) oraz paczkę słodyczy. Żołnierze wojsk indyjskich dostawali najczęściej przyprawy i słodycze, a pielęgniarki - czekoladę. Puszka na prezenty miała około 5 cali długości, 3,25 cala szerokości i 1,25 cala głębokości. W każdej znajdowała się również kartka bożonarodzeniowa z podobizną księżniczki. Ponad 355000 dostarczono na czas, na Boże Narodzenie, jednak za sprawą problemów z zaopatrzeniem w miedź wiele z nich dotarło do adresatów dopiero pod koniec stycznia 1919 roku. Pasy mosiądzu do produkcji pudełek zamówiono w Stanach Zjednoczonych, jednak ładunek przepadł wraz z zatonięciem parowca transatlantyckiego "Lusitania". Gdy fundusz ostatecznie zamknięto w 1920 roku, zebrano w nim blisko 200000 funtów, za które sfinansowano ponad dwa i pół miliona pudełek [7, 8].

\section{Palenie fajki}

W 1914 roku, gdy wybuchła I wojna światowa, palenie fajki było najpopularniejszą formą palenia tytoniu wśród europejskich żołnierzy. Niektórzy niemieccy żołnierze używali nawet specjalnie zaprojektowanych fajek z ceramicznymi główkami malowanymi w wizerunki żołnierzy pułku artylerii wraz z uzbrojeniem. Palenie fajki z czasem zaczęto też kojarzyć z oficerami armii brytyjskiej. Rycina 3 przedstawia 
obraz namalowany w 1917 roku przez Marjorie Watterson, zatytułowany The Dispatch (The Captain's Dugout) [Meldunek - Kapitańska ziemianka], przedstawiający dwóch oficerów ćmiących fajki. Fajki do palenia tytoniu stanowiły część świątecznego prezentu księżniczki Marii z 1914 roku. Również rosyjscy i francuscy żołnierze otrzymywali racje tytoniu. W następnych latach wojny palenie papierosów stało się bardziej popularne. Zapewne dlatego, że fabrycznie zapakowane papierosy były wygodniejsze w użyciu i łatwiej było je ochronić przed wilgocią w okopach niż tytoń fajkowy.

\section{„Zapakuj swoje troski i śmiej się, śmiej!”}

Jedną z najpopularniejszych piosenek marszowych w armii brytyjskiej było Pack Up Your Troubles \& Smile, Smile, Smile [Zapakuj swoje troski i śmiej się, śmiej ]. Często śpiewano również Its a Long Long Way to Tipperary [Długa droga do Tipperary]. Popularna była również Mademoiselle from Armentieres [Panienka z Armentieres], śpiewana w kilku różnych wersjach, z których niektóre były bardzo nieprzyzwoite. Słowa przywołanej w tytule piosenki odnoszą się między innymi - jakże by inaczej — do papierosów, czyli w potocznym języku — szlugów lub fajek (fags), oraz niezbędnych dla każdego palacza zapałek, nazywanych lucifers. Tekst piosenki po raz pierwszy opublikowano w 1915 roku w Londynie. Żołnierskie piosenki śpiewano nie tylko na froncie. Grywano je także w salach muzycznych ku pokrzepieniu serc zwykłych obywateli. Pamiętam je jeszcze z własnego dzieciństwa, w latach 1940 i na początku 1950. Zanim telewizja stała się powszechnie dostępna, rodziny i znajomi zbierali się wokółfortepianu i wspólnie śpiewano — również te piosenki, chociaż od I wojny światowej minęło już 30 lat. Pack Up Your Troubles \& Smile, Smile, Smile - pojawia się w kilku filmach i została przetłumaczona na różne języki, w tym na holenderski i hiszpański.

Pack up your troubles in your old kitbag And smile, smile, smile.

While you've a lucifer to light your fag, Smile boys that's the style. What's the use of worrying? It never was worthwhile, so

Pack up your troubles in your old kit bag And smile, smile, smile.

Zapakuj troski do starego plecaka I śmiej się, śmiej

Gdy macie ogień, by zapalić papierosa, Śmiejcie się chłopcy - to jest klasa. Na cóż nam zmartwienia? Nie warte są zachodu, więc Zapakuj troski do starego plecaka Iśmiej się, śmiej

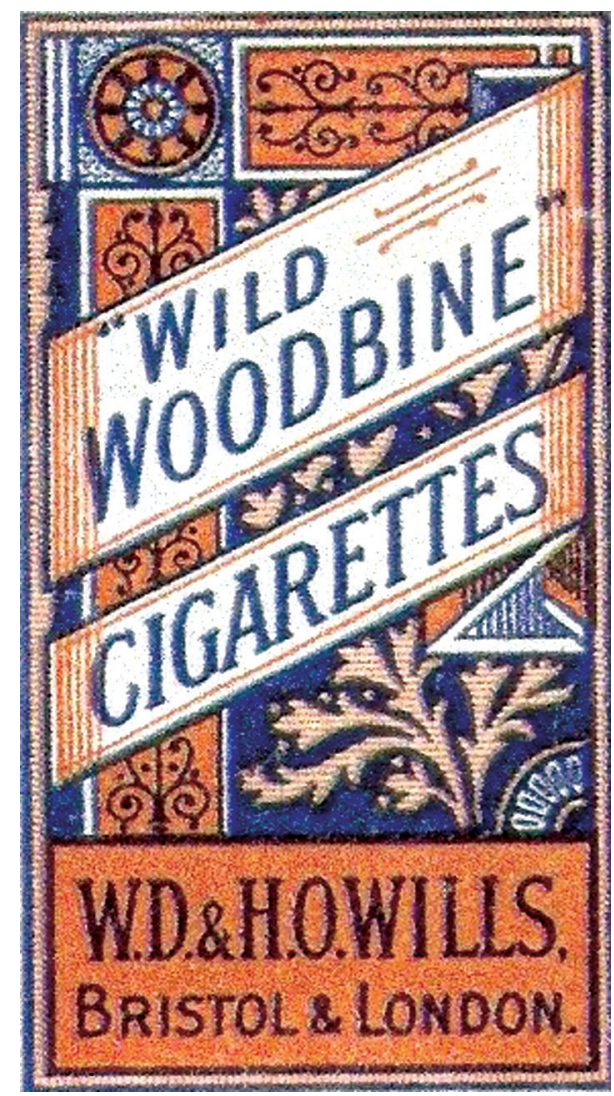

Rycina 4. Opakowanie papierosów Woodbines

\section{Woodbine Willie}

Geoffrey Studdart Kennedy (1883-1929) był anglikańskim księdzem. Podczas I wojny światowej otrzymał przezwisko Woodbine Willi, ponieważ podczas walk, niosąc duchowe wsparcie rannym i umierającym żołnierzom, rozdawał papierosy Woodbinę (ryc. 4) [9]. W roku 1914 zgłosił się na ochotnika do służby jako wojskowy kapelan na Froncie Zachodnim. W roku 1917 został odznaczony Krzyżem Wojskowym po bitwie pod Mesen, po tym jak bohatersko wbiegł na ziemię niczyją, aby pomóc rannym podczas ataku na niemiecką linię frontu. W laudacji z okazji przyznania odznaczenia [10] czytamy:

„Za niezwykłą odwagę i oddanie na służbie. Wykazał się największą odwagą i nie zważając na własne bezpieczeństwo towarzyszył rannym pod ciężkim ostrzałem. Pomagał ukryć się w wyrwach po pociskach zarówno rannym z naszych szeregów, jak i rannym wroga. Towarzyszył im do punktu opatrunkowego, a jego pogoda ducha i wytrzymałość miały niezwykły wpływ na żołnierzy wszystkich stopni w okopach na linii frontu, które nieustannie odwiedzał".

Podczas I wojny światowej Woodbine Willie z entuzjazmem popierał wojnę i został przydzielony do służby przy szkoleniu do walki na bagnety. Podróżował wraz z bokserami 


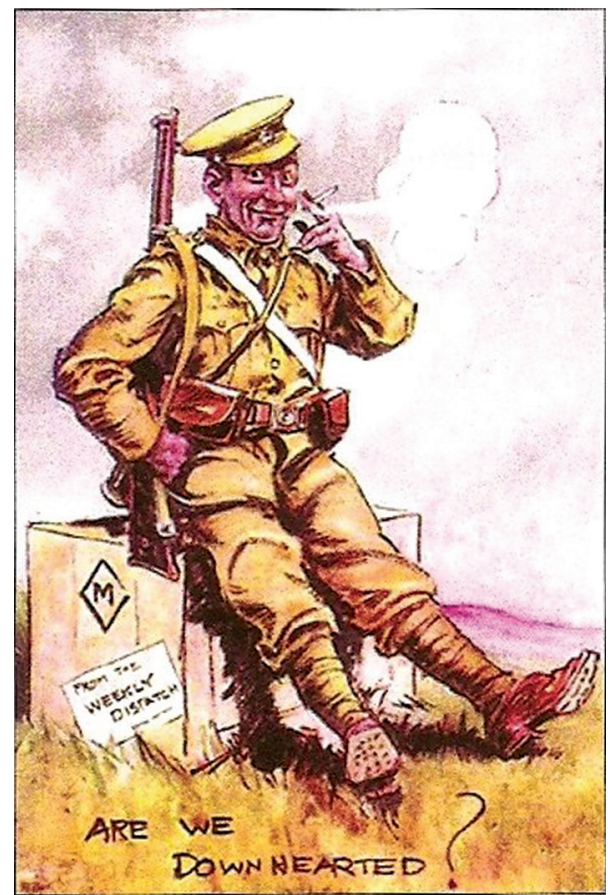

Rycina 5. Brytyjska kartka pocztowa z napisem "Czy jesteśmy przygnębieni?". Na drewnianej skrzyni znajduje się etykieta z napisem „Od Weekly Dispatch" (brytyjskiego tygodnika)

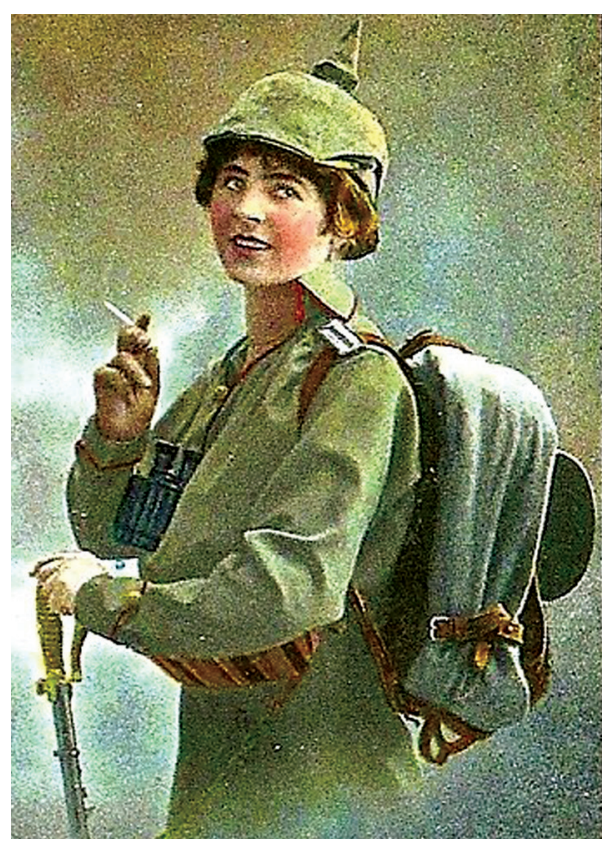

Rycina 6. Pocztówka niemiecka

i zapaśnikami, aby wspierać morale budującymi przemówieniami na temat przydatności bagnetu.

\section{Kartki pocztowe}

Setną rocznicę wybuchu I wojny światowej obchodzono na różne sposoby. Zorganizowano liczne wystawy i odczyty,

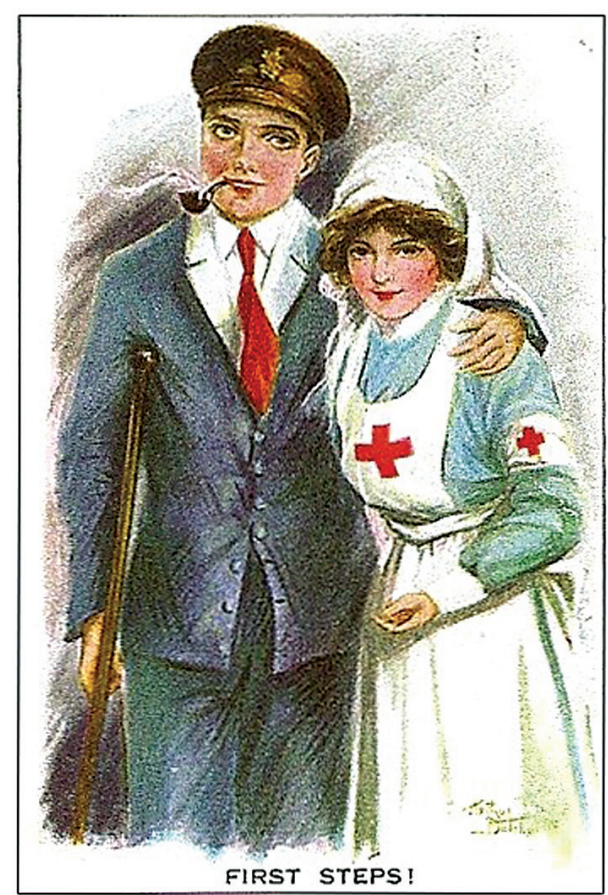

Rycina 7. Pocztówka brytyjska, podpis: „Pierwsze kroki"

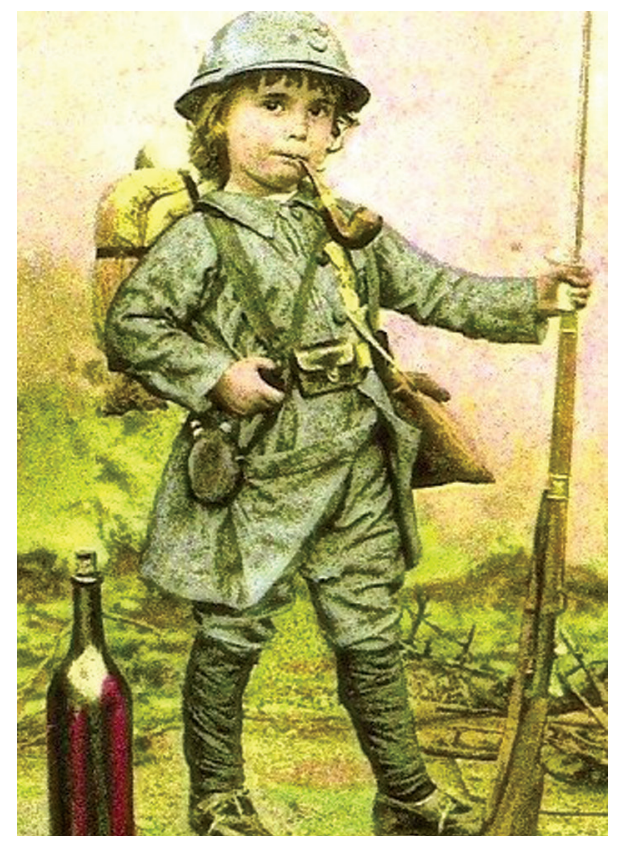

Rycina 8. Francuska kartka pocztowa. Uwagę przykuwa butelka wina w lewym dolnym rogu

ukazało się też wiele publikacji okolicznościowych. Wybrane ilustracje zaczerpnięto ze zbioru reprodukcji kartek pocztowych i rzadkich zdjęć, wydanych w formie ozdobnej tali kart [11]. Utrzymane są w lekkim tonie — cechuje je raczej humor z okopów niż realia walki, pojawiają się na nich zwykli żołnie- 


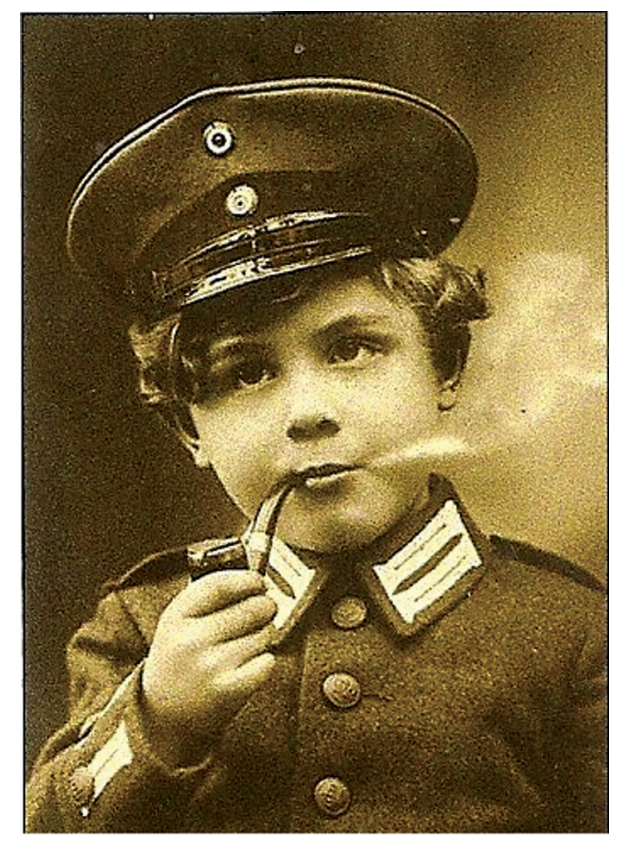

Rycina 9. Niemiecka kartka pocztowa

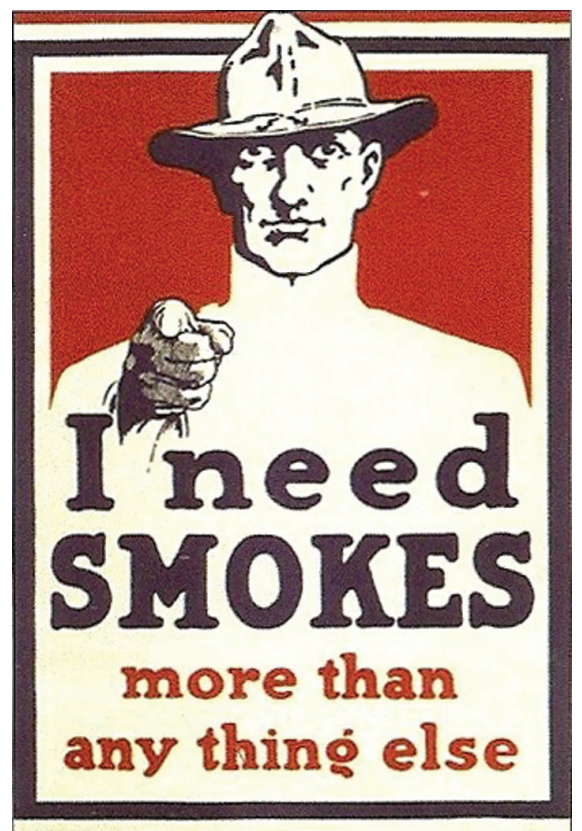

Rycina 10. Pocztówka amerykańska rze, a nie generałowie, i poczucie humoru oraz specyficzny patriotyzm spotykany raczej na tyłach niż na linii frontu. Na rycinach 5-10 przedstawiono kilka z nich. Nierzadko pojawiały się na nich kobiety (ryc. 6) oraz dzieci (ryc. 8, 9).

Pierwsze kartki pocztowe pojawiły się w Austro-Węgrzech w roku 1869. Podczas I wojny światowej były najprostszym sposobem kontaktu z bliskimi. Poeta Robert Graves, który służył w Royal Welch Fusiliers, w utrzymanej w heroikomicznym stylu wiadomości na kartce pocztowej także wspomina o papierosach: „Droga cioteczko, jestem w dobrym zdrowiu. Brodzimy we krwi aż po szyje. Przyślij mi fajki i koło ratunkowe. Ta wojna jest do kitu. Ucałowania". Żołnierze walczący na froncie, którzy mieli przepustkę tylko raz do roku, nie musieli płacić za znaczki na kartki pocztowe. Do roku 1917 Służba Pocztowej Armii Brytyjskiej każdego dnia przesyłała przez kanał La Manche 19 tysięcy worków z pocztą [11].

\section{Richard F. Mould MSc, PhD}

4, Town End Meadow

Cartmel

Grange-over-Sands

Cumbria LA11 6QG

United Kingdom

e-mail: manorroadsouthport@yahoo.co.uk

Otrzymano i przyjęto do druku: 21 stycznia 2015 r.

\section{Piśmiennictwo}

1. Mould RF. Tobacco smoking: selected images. Nowotwory J Oncol 59 (2), 59e-64e, 2009.

2. Horner L. Brangwyn at War! Cambridge \& Uppingham: Horner \& Goldmark, 2014.

3. Horner L. Brangwyn's War.Posters of the First World War. Harrogate: Mercer Art Gallery, 2014.

4. Studio talk in The Studio, vol. LXIV, no. 265, p. 199, April 1915.

5. Jünger E. Storm of Steel. London: Penguin Books 2004 (1920), p 12.

6. Remarque.EM. All Quiet on the Western Front. London: Pan Books 1987 (1929), p 7.

7. Johnson N. World War I, Part 5: Tobacco in the trenches. Blog of the Alcohol \& Drugs History Society, posted 27 June 2014.

8. Imperial War Museum archive. Princess Mary's gift to the troops, Christmas 1914. Accessed 4 October 2014.

9. Remembering the Vicar they called Woodbine Willie. Yorkshire Post 16 February 2013.

10. Military Cross Citation. The London Gazette (Supplement) No. 30234, p 8384, 14 August 1917.

11. Nicky Bird Design Ltd. Published by Bird Playing Cards, 2014 and printed in the EU by Piatnik, Vienna. 